\title{
The Relationship between the Nursing Work Load and the Quality of Nursing Care at a Selected Hospital in Menofya Governorate
}

\author{
ABEER T. ABD EL-HAMID, M.Sc.; EGLAL A. ABD EL-WAHAB, D.N.Sc. and SAHAR H. ALY, D.N.Sc. \\ The Department of Nursing Administration, Faculty of Nursing, Cairo University
}

\begin{abstract}
Background: Nursing is a critical factor in determining the quality of care in hospitals and the nature of patient outcomes and organizations are to be effective, they should have the required quality and quantity of human resource and be able to properly utilize them, additionally, nurses are key personnel in providing direct patient care. They are recommended to spend all the time with the patient, monitoring patients' conditions and delivering patient care.
\end{abstract}

Aim of Study: The current study explore the relationship between nursing workload and quality of nursing care at a selected hospital in Menofya Governorate.

\section{Subjects and Methods:}

Design: A descriptive correlational design was utilized for this study to achieve the stated aim.

Setting: The study was conducted in a selected hospital at Menofya Governorate.

Sample: Convenient sample, this sample consist of 250 nurses who working as staff nurse in all shift.

Tool: For the purpose of this study, a developed questionnaire for nurses was utilized that consist of two parts: The first part was related to the nurse work load, the second part was observational check list to assess the quality of nursing care provided.

Results: Show that nursing work load factors were perceived by staff nurses as follow: (Interpersonal factors, environmental factors, administrative factors and nursing factors) $(93.84 \%, 93.65,92.97,92.80)$, also, the study results show that the highest mean percentage of quality of nursing care dimensions that provided by staff nurses was for patient safety $(84,87 \%, 83 \%)$, while the lowest mean percentage of quality of nursing care dimensions that provided by staff nurses was for nursing factor $(31,65 \%)$.

Conclusion: The present study concluded that there was no statistical significant corerelation between nursing work load and quality of nursing care.

Correspondence to: Dr. Abeer T. Abd El-Hamid, The Department of Nursing Administration, Faculty of Nursing, Cairo University
Recommendations: Hospital should assess nursing work load factors periodically to use results for creation of positive work atmosphere for productivity and quality of nursing care should be assessed periodically to assure meting the quality standards for protection the patient safety.

Key Words: Nursing work load - Quality of nursing care.

\section{Introduction}

NURSES are usually the first to notice subtle changes in patient condition and are in an optimal position to respond quickly should their patients need it. Therefore, it is imperative that nurse staffing match patient needs. Measuring nurses' workloads adequately is critical to ensuring safe patient care; however, a widely accepted workload measure remains elusive due to its complex nature. On the other hand increasing healthcare human resource shortages, constrained health care budgets, and quality and safety concerns have resulted in many workforce redesign initiatives within health care [1,2].

Nursing work load can be defined as function of environmental and organizational factors. Additionally, nursing work load is made up of nursing and non nursing tasks or activities. Nursing tasks are the numbers of nursing duties. These are the activities carried out by a nurse during a shift. It include patient assessment, developing care plans and providing comprehensive nursing care. Non nursing tasks and activities refers to the activities carried out by a nurse during a shift which does not require professional nursing skills and are not related to direct patient care. It include clerical work, house keeping, dietary services and transporting patients $[3,4]$

Measuring nursing work load has a great importance as it is reliably the critical initial step to 
understanding the relationship between workload, nursing retention and patient safety. However, ignoring the importance of its measurement may cause a negative impact on the quality and safety of care to patients, therefore, the assessment of nursing workload is a subject of great relevance, insofar as an oversized team implies higher costs. On the other hand, it is known that a reduced team can cause a drop in effectiveness and/or quality of care, extending the length of hospital stay and generating greater costs of treatment, in addition to exposing patients, staff, and the institution itself to the risk of not having safe care. Results from this work may be useful in creating measures that offer amore comprehensive and accurate estimate of nurses' workloads. Better estimates of nurse workloads would allow managers and administrators to better allocate nursing resources based on patient [5-7].

Virtually, high workload affects health of the employees seriously when it lasts for longer period of time leading to paralyzing performance in work since sound health is the primary deciding factor of job performance in the workplace. As cleanliness environment is mainly associated with performance of sanitary workers, when performance and contribution of sanitary workers go down, naturally cleanliness and hygienic aspects of the hospital will be worsening causing high infection rate which will further interfere in recovery of the patients from sickness and reduce not only safety of the patients but also lower satisfaction and reliability of patients and their relatives [8]

Quality of nursing care is defined as a process that sought to attain the highest degree of excellence in the delivery of patient care. It can be defined as the degree to which health services for individuals and populations increase the likelihood of desired health outcomes and are consistent with current professional knowledge [9-12].

Quality nursing care remains an important role for patient because nurses are involved in almost every aspect of client's care in hospital. Nurses also interact with patients more often than any other health care personnel in a hospital. Further more, quality of nursing care help nurse to make care safer by reducing harm caused in the delivery of care, strengthen person and family engagement as partners in their care, promote effective communication and coordination of care. Prevention and treatment of chronic disease, work with communities to promote best practices of healthy living and make care affordable [13]
There is a great relationship between nursing workload and quality of nursing care as it is a known fact that larger patient numbers distributed to an insufficient number of nurses are linked to adverse events and decreased patient satisfaction. On the other hand, service quality is affected by the imbalance between the number of personnel and the workload of nurses in a hospital as high workload can lead to stress and a decline in the quality of nursing care [14].

\section{Significance of the study:}

Health workforce is the main factor in providing hospital success, as nearly fifty percent to eighty percent of costs are allocated to workforces. Nurses are the most important and largest workforce with a vital role in the quality of care and health promotion, so nurses contribute to the progress of healthcare organizations more than other professionals. Accordingly, sufficient nursing workforce is essential for optimal nursing care [15].

Nursing is an accountable profession guided by science, theory, code of ethics and the art of care and comfort to treat human responses to health and ill patients satisfaction with care, so nursing care is considered as an important factor in explaining patient's perception of service quality. In addition to that nurses are frontline care providers and remain with the patient round the clock so nursing care is one of the major components of healthcare services. It is the duty of the nurses to provide quality care to satisfy patient's needs. Nurses and physicians perceptions about good quality of care do not always agree with patient's perceptions $[16,17]$

\section{Research questions:}

1- What is the nursing work load?

2- What is the quality of nursing care?

3- What are the contributory factors that lead to high nursing work load?

4- What is the relationship between nursing workload and quality of nursing care?

\section{Subjects and Methods}

\section{Research design:}

Descriptive correlational design was utilized to achieve the aim of this study.

Setting:

The current study was carried out at a selected hospital in Menofya Governorate, all departments were included. 


\section{Subjects:}

A convenient sample of staff nurses working in all units of the hospital during day and night in permanent and rotatory shift in the hospital was included in the study. Total population of nurses 285 nurses. Study sample was consisted of [218] nurses working as a staff nurse in all shifts and [32] nurse working as a head nurse in the morning shift only but as a staff nurse in afternoon and night shift at different departments (i.e., ICU, medical and surgical section) [totally 250 nurses]. according to the following inclusion criteria:

1- Worked in the hospital for at least one year.

2- Give direct patient care.

3- Actively working during data collection.

4- Agree to participate in the study.

Tools of data collection: Data was collected through utilizing two tools:

A- The first tool was nursing work load questionnaire. It is a modified tool that based on review literature, it answered by staff nurse, to assess nurse to patient ratio and perceived contributory factors that affect nursing work load.

\section{The tool was consisted of three sections:}

1- A self-administered questionnaire: It was used to obtain the personal data of study participants:

It includes age, sex, marital status, level of education, position, years of experience in nursing and years of experience in the current position.

2- Workload on the shift was measured using the number of patients assigned to each nurse during the shift in usual time and in emergency time. (Nurse-patient ratio).

3- Factors contributing to the increasingof nursingworkload. Theyconsisted of four categories: Environmental factors (15 items), administrative factors (13 items), interpersonal factors (6 items), and nursing factors (14 items). Responses measured against 3 points Likert scale 3 for agree, 2 for neutral, 1 for disagree.

B- The second tool was the observational check list for quality of nursing care provided by nurses. It is a modified tool based on the national standards of care.

\section{It consisted of three domains:}

1- Patient safety domain: It includes (15 items), (6 items) related to patient care and (9 items) related to medication management.
2- Nursing care domain: It includes (4 items).

3- Infection control domain: It includes (8 items).

The observed behavior was measured against 4 points Likert scale. $(\mathrm{Met})=3$ (done at all times), (partially Met) $=2$ (some times i.e. not all the times met/not all the sub items met), $\mathrm{N}=($ Not Met $)=1$ (not done most of the time); and NA (Non Applicable $=0$ (not applicable or not available in the healthcare setting).

\section{Methods of data collection:}

Consent to conduct the study was taking from the vice dean of graduate studies at Faculty of Nursing, Cairo University, and hospital administrator. The tools were reviewed by jury consisted of five professors in nursing administration to be tested for its content validity. Data were collected in five months from October 2017 to February 2018.

The investigator emphasis that, participation in the study is voluntary and anonymity and confidentiality of the subject's responses were assured. The nurses who met the inclusion criteria were identified by the investigator and asked for participation in this study in different shift work. The investigator explained to the subjects the purposes, benefits and ethical considerations of this study.

As regards the staff nurses who worked at morning shift and who agreed to participate in this study completed the questionnaire during break times and taken by the investigator in the same day. Meanwhile, the investigator had met afternoon and night shifts worked nurses at the beginning of a night shift to distribute the questionnaire to them. The questionnaire which had been filled in was taken by the investigator in the next day or after two days. As regards observation of nurses, it was done intermittently, three sessions per week, two hours each for two weeks. Arrangement was done with unit managers to meet with the nurses in their units.

\section{Ethical considerations:}

Before commencing the study, ethical approval was granted from the research ethics committee in which the study took place. The researchers ensured that the correct procedures were undertaken concerning informed consent, autonomy, anonymity and the maintenance of confidentiality.

\section{Statistical analysis:}

The collected data will be categorized, scored, tabulated, and analyzed by computer using Statistical Package for Social Science (SPSS). Descrip- 
tive statistics will be used in the form of frequency distribution and percentages. Appropriate statistical test were applied for data analysis.

\section{Results}

Table (1) shows that the majority of the nurses $(93.6 \%)$ were female, they were married $(88.8 \%)$, highest percentage of them had technical nursing diploma (69.2\%) and working as a staff nurses $(87.2 \%)$. As regards to respondats age, the mean age was $34.2 \pm 5.2$, while the mean of their years of experience in nursing profession was $7.1 \pm 1.6$ compared to $7.02 \pm 1.7$ years of experience in their curent position. The mean score of patients' number assigned in usual time was $3.5 \pm 1.5$ compared to patients number assigned in emergency was $6.7 \pm$ 2.2.

Table (1): Frequency distribution of study sample socio demographic characteristics $(n=250)$.

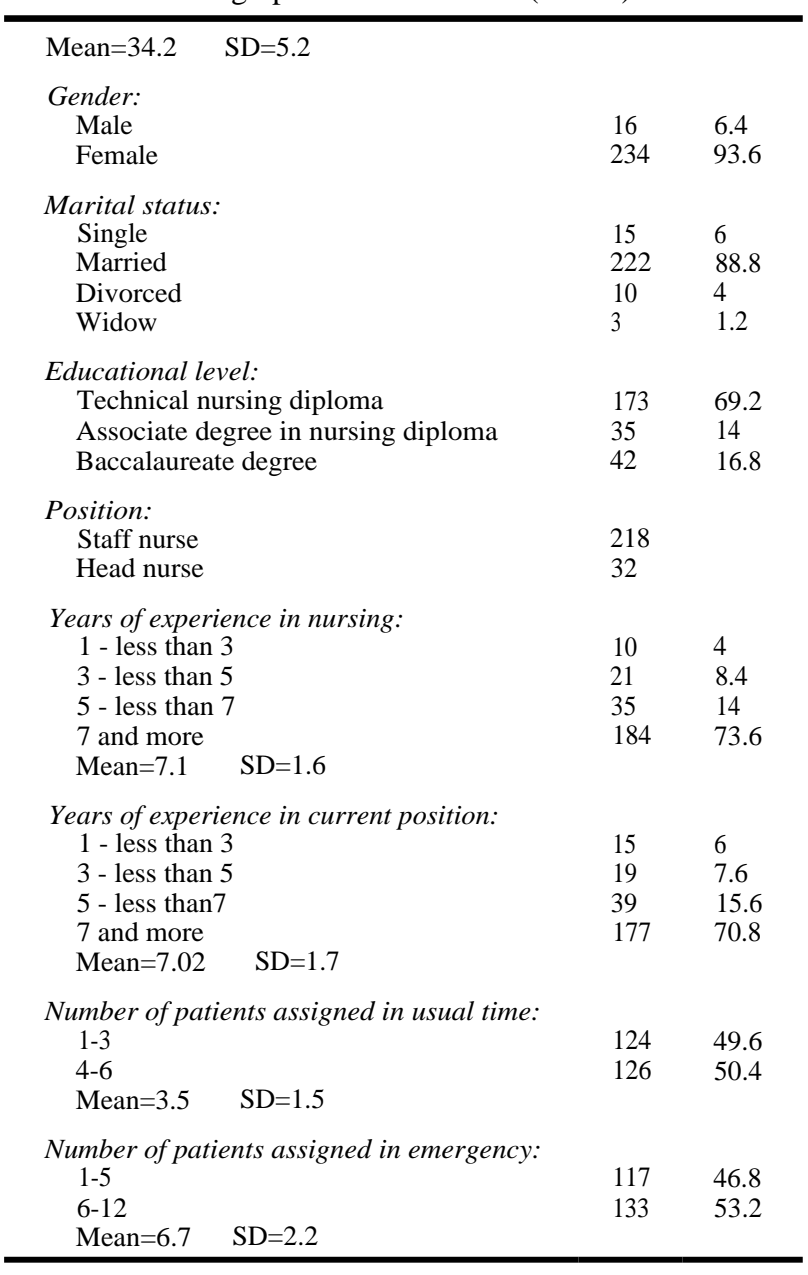

Table (2) show that nursing work load factors were perceived by staff nurses as follow: (Interpersonal factors, environmental factors, administrative factors and nursing factors) (93.84\%, 93.65, 92.97, 92.80).
Table (2): Mean and mean percentage of nursing work load factors as perceived by study participants $(n=250)$.

\begin{tabular}{lclcc}
\hline Dimensions & Mean score & SD & Max score Mean percent \\
\hline Environmental factors & 42.14 & 5.44 & 45 & 93.65 \\
Interpersonal factors & 16.89 & 12.36 & 18 & 93.84 \\
Administrative factors & 36.26 & 7.04 & 39 & 92.97 \\
Nursing factors & 38.98 & 7.23 & 42 & 92.80 \\
\hline Total work load & 134.27 & 4.28 & 144 & 93.24 \\
\hline
\end{tabular}

Table (3): Show that the highest mean percentage of quality of nursing care dimensions that provided by staff nurses was for patient safety $(84,87 \%, 83 \%)$. While the lowest mean percentage of quality of nursing care dimensions that provided by staff nurses was for nursing factor $(31,65 \%)$.

Table (3): Mean and mean percentage of quality of nursing care dimensions provided by study participants as observed.

\begin{tabular}{lllll}
\hline Dimensions & $\begin{array}{c}\text { Mean } \\
\text { score }\end{array}$ & SD & $\begin{array}{c}\text { Max } \\
\text { score }\end{array}$ & $\begin{array}{c}\text { Mean } \\
\text { percent }\end{array}$ \\
\hline 1- Patien safety: & & & & \\
$\quad$ A- Patient care & 9.96 & 11.57 & 12 & 83.00 \\
$\quad$ B- Medication management & 15.28 & 11.17 & 18 & 84.87 \\
2- Nursing factors & 2.53 & 15.49 & 8 & 31.65 \\
3- Infection control & 5.09 & 10.24 & 16 & 31.83 \\
\hline Total quality of nursing care & 31.23 & 6.82 & 54 & 57.84 \\
\hline
\end{tabular}

Table (4): Show that there is a statistical highly significant correlation between nursing workload environmental factors and patient safety dimensions $(p=0.04)$. Also, there is a statistical significant correlation between nursing workload interpersonal factors and nursing and infection control dimensions ( $p=0.03$ and 0.002 respectively). There is a statistical significant correlation between nursing workload factors and patient safety dimensions $(p=0.005)$.

Table (4): Correlation between nursing work load factors and quality of nursing care dimensions.

\begin{tabular}{llllllll}
\hline $\begin{array}{l}\text { Quality of nursing } \\
\text { care dimensions }\end{array}$ & \multicolumn{2}{c}{$\begin{array}{c}\text { Patient } \\
\text { safety }\end{array}$} & \multicolumn{2}{c}{$\begin{array}{c}\text { Nursing } \\
\text { care }\end{array}$} & $\begin{array}{l}\text { Infection } \\
\text { control }\end{array}$ \\
\cline { 2 - 8 } & $r$ & $p$ & $r$ & $p$ & $r$ & $p$ \\
\hline Nursing workload factors: & & & & & & \\
$\quad$ Environmental factors & -0.12 & $0.04 *$ & -0.09 & 0.11 & -0.03 & 0.57 \\
$\quad$ Interpersonal factors & 0.11 & 0.06 & 0.13 & $0.03 *$ & 0.19 & $0.002 *$ \\
Administrative factors & -0.07 & 0.24 & 0.07 & 0.23 & 0.01 & 0.78 \\
$\quad$ Nursing factors & -0.17 & $0.005^{*}$ & -0.03 & 0.57 & -0.08 & 0.16 \\
\hline
\end{tabular}

*: Significant.

Table (5) this table show that there was no statistical significant relation between nursing work load and quality of nursing care $(p=0.38)$. 
Table (5): Correlation between nursing work load and quality of nursing care among study respondents $(n=250)$.

\begin{tabular}{llc}
\hline \multirow{2}{*}{ Variables } & \multicolumn{2}{l}{ Quality of nursing care } \\
\cline { 2 - 3 } & $r$ & $p$ \\
\hline Nursing workload & -0.05 & 0.38 \\
\hline
\end{tabular}

\section{Discussion}

It is noticed from the current study that all percentages of nursing work load dimensions which include (environmental, personal, administrative and nursing) are near from each other which mean presence of all factors in the hospital which generated a great work load. This work load require a great efforts from the managers and administrators to reduce it and try adaptation with factors that increase it.

Also as regards to quality of nursing care dimensions it is noticed that patient is the first person suffering from nursing work load as it prevent nurse from providing the ideal care to him and may harm his safety. These results were supported by [18] and [19], whose results indicated that patient safety is an important dimension of quality and patient safety and satisfaction levels increased with increasing level of application of the quality standards by the nurses.

As regards to nursing work load factors and quality of nursing care dimensions these results were supported by [20] and [21], whose results indicated that there was high positive correlation observed between the workload of the services and patient safety incidents and mortality. Also these results showed that nursing workload, analyzed by different instruments, had an impact on patient safety and the occurrence of adverse events in patients during hospitalization in which generate an impact on the quality of care, with increased rates of mortality, longer hospital stays and, consequently, higher welfare costs.

In the same line of these results, another studies conducted by $[\mathbf{2 2 , 2 3 ]}$, indicated that there is a complex and non-linear relationship between Nursing Workload (NWL), patient outcomes and patient safety. Also, these results revealed that the perception by nurses of having adequate staffing and resources and lower nursing work load was positively correlated to their personal assessment of patient safety as a whole. On the other hand, insufficient nurse staffing in hospital-based care lead to nursing work load which negatively affects patient outcomes such as infection. Moreover, these results were congruent with $[\mathbf{2 4 , 2 5 ]}$ whose results indicated that an inadequate staffing (higher numbers of patients assigned to nursing professional) has a negative impact on safety for patients.

These results were contradicted by [25,26], whose results indicated that there is no significant changes in patient safety associated with decreased nursing work load. Also these results assert a trusting relationship between employees and management (interpersonal factors) supports a healthy work environment enhancing staff retention and effective patient care (patient care dimension) not infection control dimensions.

As regards to correlation between nursing work load and quality of nursing care among study respondents, this result was supported by [27-29], whose results indicated that increased workload leads to lower quality of patient care and it was appearing to be an important organizational variable linked with quality of care because insufficient number of nursing staff lead to nursing work load which reduce the quality of care, prolonged hospital stay, and increase the risk of potential complications. In addition to that, this result was supported by the result of [30-32], whose results indicated that nurses' workload have been related to nurse assessed quality of care as it was an important determinant of quality of care. Also they reported that there was a direct relationship between nurses' workload and nurse-reported quality of care

Moreover, this result was supported by [33-36] whose results revealed that nursing work load affects care quality and mortality as it has strong relation with the quality of the care output that provided by the nurses so quality of nursing care can be improved by balanced distribution of workforce relative to workload in different shifts.

Finally the current study findings indicate that there was a negative correlation but not statistically significant relation between nursing work load and quality of nursing care.

\section{Conclusion:}

The present study concluded that there was no statistical significant relation between nursing work load and quality of nursing care $(p=0.38)$.

\section{Recommendations:}

In the light of the findings of the present study, the following are recommended:

1- Stratigies to improve nurses working load such as safe staffing ratio.

2- Improve quality of nursing care. 
3- Nurse manager should develop policies and guidelines for safety practice mainly infection control practice.

4- Hospital should assess nursing work load factors periodically to use results for creation of positive work atmosphere for productivity.

5- Quality of nursing care should be assessed periodically to assure meting the quality standards for protection the patient safety.

\section{References}

1- TWIGG D. and DUFFIELD C.: A review of workload measures: A context for a new staffing methodology in Western Aus-tralia. International Journal of Nursing Studies, 46 (1): 132-40, 2009.

2- MacPHEE M.: Valuing Patient Safety: Responsible Workforce Design, 1 st ed.; Canadian Federation of Nurses Union: Ottawa, ON, Canada, 2014.

3- XIE B. and SALVENDY G.: Review and reappraisal of model-ing and predicting mental workload in single-and multi-taskenvironments. Work Stress, 14: 74-99, 2011.

4- MIRANDA D.R., NAP R., De RIJK A., SCHAUFELI W. and IAPICHINO G.: Tiss Working Group. Therapeutic Intervention Scoring System. Nursing activities score. Crit. Care Med., 31 (2): 374-82. Doi: 10.1097/01 CCM.0000045567.78801.CC. [PubMed: 12576939, 2012.

5- HILL C.: The impact of unacceptable wait time on health care patients' attitudes and actions. Health Marketing Quarterly, 23 (2): 69-87, 2010.

6- ANDERSON R.: Multivariate Data Analysis. New Jersey: Pearson/Prentice Hall, 2010.

7- TANOS M.A.A., MASSAROLLO M.C.K.B. and GAIDZINSKI R.R.: Dimensionamento de pessoal de enfermagem em uma unidade especializada em transplante de fígado: Comparação do real com o preconizado. Rev. Esc. Enferm. USP [Internet], [citado 2015 Nov. 15]; 34 (4): 376-82, Disponível em: http://www.scielo.br/pdf/reeusp/ v34n4/v34n4a09, 2000.

8- RAJAN D.: Negative impacts of heavy workload: A comparative study among sanitary workers. Sociol Int. J., 2 (6): 465-74. Doi:10.15406/sij.2018.02.00086, 2018.

9- BEKEMEIER B.: Credentialing for Public Health Nurses: Personally valued but not recognized. Public Health Nursing, 24 (5): 439-48, 2009.

10- COOPER: Students' perceptions of bullying behaviors by nursing faculty. Issues in Educational Research, 21 (1): 1-21. Retrieved from http://www.iier.org.au/iier21/cooper html, 2011.

11-ALLIGOOD M.R. and BURHANS L.M.: Quality nursing care in the words of nurses. Journal of Advanced Nursing, 66 (8): 1689-97. Doi: 10.111 1/j. 1365-2648.2010.05344.x, 2010.

12- AIKEN L.H., SLOANE D.M., BRUYNEEL L., VAN DEN HEEDE K., SERMEUS W. and CONSORTIUM R.C.: Nurses' reportsof working conditions and hospital quality of care in 12 countries in Europe. Int. J. Nurs. Stud., 50: 143-53, [CrossRef] [PubMed], 2013.
13- STEINER: What exactly does quality mean in the healthcare context? | October 16, 2017.

14- HAMIM N.: Workload and work stress on caring behavior in nurse on nursing services. International Journal of Human Resource Studies, 5 (3): 148-60, 2015.

15- HECKEMANN B., ZELLER A., HAHN S., DASSEN T., SCHOLS J.M. and HALFENS R.J.: The effect of aggression management training programmes for nursing staff and students working in an acute hospital setting. A narrative review of current literature. Nurse Educ. Today, 35 (1): 212-9. Doi: 10.1016/j.nedt.2014.08.003. [PubMed: 25200511], 2015.

16- RAJESWARI T.: A study to assess patient's satisfaction with quality of nursing care, 11: 15-71, 2018.

17- GITA DHAKAL CHALISE: How the Patient Perceives about Nursing Care: Patient Satisfaction Study using SERVQUAL Model, Galore International Journal of Health Sciences and Research Vol. 3; Issue: 2; April-June 2018 Website: www.gijhsr.comOriginal Research Article P-IS0053N: 2456-9321.

18- RUNCIMAN W.: Towards an International Classification for Patient Safety: Key concepts and terms. Int. J. Qual. Health Care, 21: 18-26, 2009.

19- TENG C., YEA-ING L., SHYU R.N. and YU-TZU DAI RN: Nursing accreditation system and patients afety. J. Nursing Manag., 20: 311-8, 2012.

20- VENTURA C.M.U., ALVES J.G.B. and MENESES J.A.: Eventos adversos em Unidade de Terapia Intensiva Neonatal. Rev. Bras. Enferm. [Internet], [Citado $2016 \mathrm{fev}$. 10]; 65(1): 49-55. Disponível em: http://www.scielo.br/ pdf/reben/v65n1/07.pdf, 2012.

21- Ministerio de Salud Chile [Internet]. Norma técnica N 154 sobre Programa Nacional de Calidad y Seguridaden la Atención. Reglamentos para la seguridad delpaciente [Acceso 25 Junio 2014]. Disponibleen: http://www. supersalud.gob. cl/observatorio/575/articles-

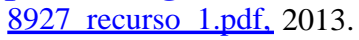

22- NEEDLEMAN J., BUERHAUS P., PANKRATZ V.S., LEIB SON C.L., STEVENS S.R. and HARRIS M.: Nurse Staffing and inpatient hospital mortality. N. Engl. J. Med., 364 (11): 1037-45, 2011.

23- ZINGG W., HOLMES A., DETTENKOFER M., et al.: Hospital organisation, management, and structure for prevention of health-care-associated infection: A systematic review and expert consensus. Lancet Infect Dis., 15: 212-24. Doi: 10.1016/S1473-3099(14)70854-0, 2015.

24- MAGALHÃES A.M.M., COSTA D.G.D., RIBOLDI C.O., et al.: Association between workload of the nursing staff and patient safety outcomes. Rev. Esc. Enferm. USP, 51: e03255. [Crossref] [PubMed, 2017.

25- FAGERSTRÖM L., KINNUNEN M. and SAARELA J.: Nursing workload, patient safety incidents and mortality: An observational study from Finland BMJ Open, 8: e016367. Doi: 10.1136/bmjopen-2017-016367, 2018.

26- MULLARKEY M., DUFFY A. and TIMMINS F.: Trust between nursing management and staff in critical care: A literature review. British Association of Nursing in Critical Care, 16 (2): 85-91, 2011.

27- AIKEN L.H., CIMIOTTI J., SLOANE D.M., SMITH H.L., FLYNN L. and NEFF D.: The effects of nurse 
staffing and nurse education on patient deaths in hospitals with different nurse work environments. Med. Care, 49: 1047-53, 2011.

28- LIN S.Y., CHIANG H.Y. and CHEN I.L.: Comparing nurses' intent to leave or stay: Differences of practice environment perceptions. Nursing \& Health Sciences, 13: 463-7, https://doi.org/10.1111/j.1442-2018.2011.00640.x, 2011.

29- PAPASTAVROU, ANDREOU and EFSTATHIOU: Reviewed 17 quantitative studies and found that workload was a potential cause of rationing, and nurse-related outcomes included low job and occupational satisfaction, with rationing appearing to be an important organisational variable linked with patient safety and quality of care, 2013.

30- BRUYNEEL L., VAN DEN HEEDE K., GRIFFITHS P., BUSSE R., et al.: Nurse staffing and education and hospital mortality in nine European countries: A retrospective observational study. Lancet, 383 (9931): 1824-30. Doi: 10.1016/S0140-6736(13)62631-8. [PubMed: 24581683, 2014.

31- SOCHALSKI J.: Is more better? The relationship between nurse staffing and the quality of nursingcare in hospitals. Med. Care, 42 (2): II67, 2014.
32- MYNY D., VAN GOUBERGEN D., GOBERT M. VANDERWEE K., VAN HECKE A. and DEFLOOR T.: Non-direct patient care factors influencing nursing workload: A review of the literature. J. Adv. Nurs., 67: 210929, 2014.

33- CHO E., SLOANE D.M., KIM E.Y., KIM S., CHOI M., YOO I.Y. and AIKEN L.H.: Effects of nurse staffing, work environments, and education on patient mortality: An observational study. International Journal of Nursing Studies, 52 (2): 535542. https://doi.org/10.1016/j.ijnurstu 2014. 08.006, 2015.

34- CAUDROS K.C., PADILHA K.G., TOFFOLETTO M.C., HENRIQUEZ-ROLDAN C. and CANALES M.A.J.: Patient safety incidents and nursing workload. Rev. LatinoAm. Enfermagem., 25 https://doi.org/10.1590/15188345.1280.2841, 2017.

35- MOMENNASAB M., KARIMI F., DEHGHANRAD F. and ZARSHENAS L.: Evaluation of Nursing Workload and Efficiency of Staff Allocation in a Trauma Intensive Care Unit, Trauma Mon., 23 (1): e58161. doi: 10.5812/ traumamon.58161, 2018.

36- AL-MALKI M.: "Factors influencing the ice nurses workload. "IOSR Journal of Nursing and Health Science (IOSR-JNHS), Vol. 7, No. 3, pp. 01-04, 2018.

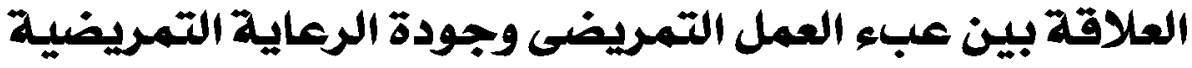

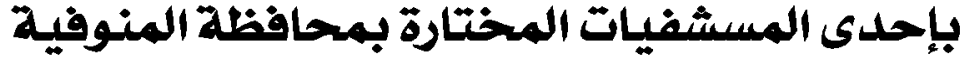

التمريض يعتبر عامل حيوى فى تصديد جودة الرعاية المقدمة بالمستشفيات ولكى تككن نتائج هذه الرعاية فعالة لابد آن يتوفر كمية كافية

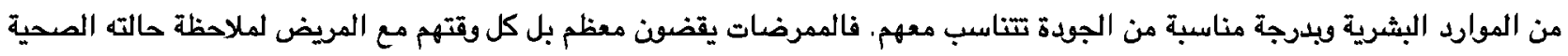

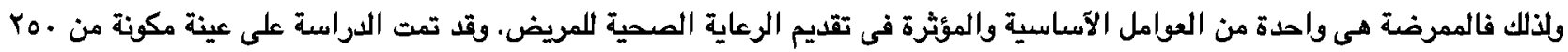

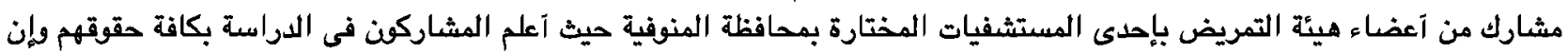

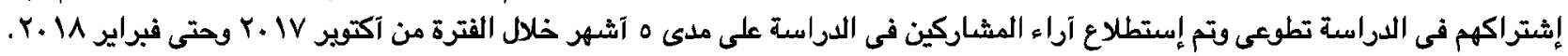

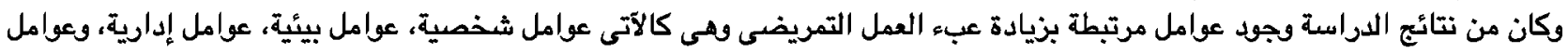

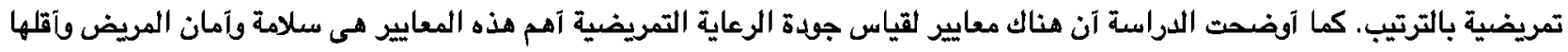

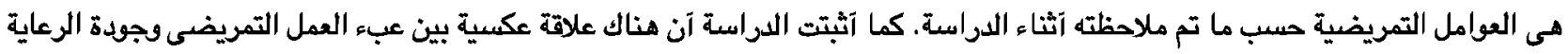
التمريضية. وبعد الإنتهاء من الدراسة فقد آقترح الباحث لعمل آليات لقياس عبء العمل التمريضى وكنالك آليات لقياس جولدة الرعاية التمريضية

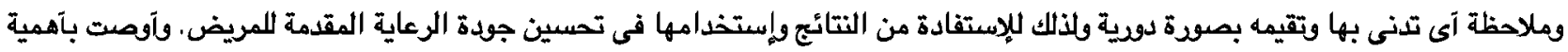

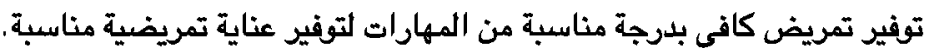

